\begin{tabular}{l|c|r}
\hline ISSN: 0001-5113 & ACTAADRIAT., & SHORT COMMUNICATION \\
AADRAY & 58(1): 187 - 192, 2017 & \\
\hline
\end{tabular}

\title{
Length-weight relationships of 9 commercial fish species from the North Aegean Sea
}

\author{
Athanasios EVAGELOPOULOS*, Ioannis BATJAKAS and Drosos KOUTSOUBAS \\ Department of Marine Sciences, University of the Aegean, 81100, Mytilene, Greece \\ *Corresponding author, e-mail: tevagelo@marine.aegean.gr
}

\begin{abstract}
Length-weight relationships are presented for 9 commercial fish species from Psara Island (North Aegean Sea). The species studied are Boops boops, Dentex maroccanus, Helicolenus dactylopterus, Merluccius merluccius, Mullus surmuletus, Pagrus pagrus, Raja clavata, Scyliorhinus canicula and Trachurus picturatus. To our knowledge, there are no published data on the fish stocks of the study area. Estimates of LWR parameters are provided for Dentex maroccanus, Trachurus picturatus and Helicolenus dactylopterus, for which reliable LWR datasets are few in the literature, while none has been published for the Greek seas. The samples were collected from the continental shelf and the upper slope, by using non-selective fishing gear (with a research vessel and a commercial bottom trawler), during two seasonal sampling periods: November 2009 and May 2010. The growth pattern of Boops boops and Scyliorhinus canicula was found to be positive allometric, whereas an isometric growth pattern was determined for the other species in the study. We hope that the LWR obtained here will be used in future fisheries management or conservation research in the study area, for example, to convert lengths to weights, determine fish condition and assess spatial or temporal variability in fish growth.
\end{abstract}

Key words: life history, animal growth, fishery management, demersal fisheries, bottom trawling

\section{INTRODUCTION}

The length-weight relationship (LWR) in fish is described by the power function $\mathrm{W}=\mathrm{aL}^{\mathrm{b}}$, where $\mathrm{W}$ is weight, $\mathrm{L}$ is length and $\mathrm{a}$ and $\mathrm{b}$ are the species-specific parameters of the function, which can be estimated by regression analysis (LE CREN, 1951). The LWR is related to fish condition and is affected by life-history stage, sex, nutritional state, season and area (LE CREN, 1951; JENNINGS et al., 2001; FROESE, 2006). Even after fish obtain adult body shape during their ontogenetic development, their shape may vary during growth in relation to size (positive or negative allometric growth, $\mathrm{b}>3$ or $\mathrm{b}<3$, respectively), or not (isometric growth, $b=3$ ). The parameters of the LWR relationship can be calculated from subsamples and are commonly used in fisheries management or conservation research to convert lengths to weights, determine fish condition and assess spatial or temporal variability in fish growth (FROESE et al., 2011).

The aim of this study is to present novel information for the length-weight relationships and growth patterns for 9 commercial fish species from Psara Island (North Aegean). The species studied are Boops boops, Dentex maroc- 
canus, Helicolenus dactylopterus, Merluccius merluccius, Mullus surmuletus, Pagrus pagrus, Raja clavata, Scyliorhinus canicula and Trachurus picturatus.

\section{MATERIAL AND METHODS}

Length and weight data for 9 commercial fish species from the southernmost part of the North Aegean Sea (Greece) were used to describe the LWR of the species. The study area extends from the west of Psara and Antipsara Islands to the north of Chios Island (Fig. 1).

The samples were collected with bottom trawling from the continental shelf and the upper slope (depths $30-500 \mathrm{~m}$ ), onboard R/V Philia of HCMR and the Venus II commercial trawler, in November 2009 and May 2010. Trawling methodology was kept similar between vessels and all trawls had the same cod end mesh size of $20 \mathrm{~mm}$ and trawling speed of 3 knots. Total Length (TL) to the nearest $\mathrm{mm}$ and weight in $\mathrm{g}$ of the individuals in the catches were measured onboard. Where large numbers of individuals from a species were caught, the length and weight measurements were carried out in subsamples of the catches (100 specimens following FROESE et al., 2011). The parameters a and $b$ of the LWR were estimated by applying ordinary least squares linear regression. Following the guidelines of FROESE et al. (2011), we removed from the data influential observations, i.e. outliers (data points whose response y values did not follow the general trend of the remain- ing data) and high leverage observations (data points that had particularly high or low predictor $\mathrm{x}$ values). This was accomplished by calculating Cook's distance D for each observation, using the following cut-off rule: $D_{i}>4 /(n-k-1)$, where $D_{i}$ is Cook's distance for observation $i, n$ is the total number of observations and $\mathrm{k}$ is the number of independent variables (FOX, 1997). In order to check for allometric growth, i.e. test the regression slope against the value 3 , we reparameterized the original regression model $\mathrm{y}=\beta_{0}+\beta_{1} \mathrm{x}$ (where $\mathrm{y}=\log \mathrm{W}, \mathrm{x}=\log \mathrm{L}, \beta_{0}=$ loga and $\beta_{1}=b$ ) into $y-3 x=\beta_{0}+\theta x$. A test of significance for the new model against the null hypothesis $\mathrm{H}_{0}: \theta=0$ is equivalent to a test of significance for the original model against $\mathrm{H}_{0}$ : $\beta_{1}=3$. All data analyses were carried out with $\mathrm{R}$ (R CORE TEAM, 2017; https://www.r-project.org/). The taxonomy and nomenclature are in accordance with FishBase (FROESE \& PAULY, 2017; http://www. fishbase.org).

\section{RESULTS AND DISCUSSION}

A total of 755 individuals were sampled to provide estimates of LWR (see Table 1). The coefficient of determination for the majority of the regressions was $\geq 0.94$ and all slopes were significant $(p<0.001)$. $b$ values ranged from 2.905 to 3.559 and growth was found to be positive allometric for Boops boops and Scyliorhinus canicula $(\mathrm{p}<0.05)$, whereas an isometric growth pattern was determined for the other species.
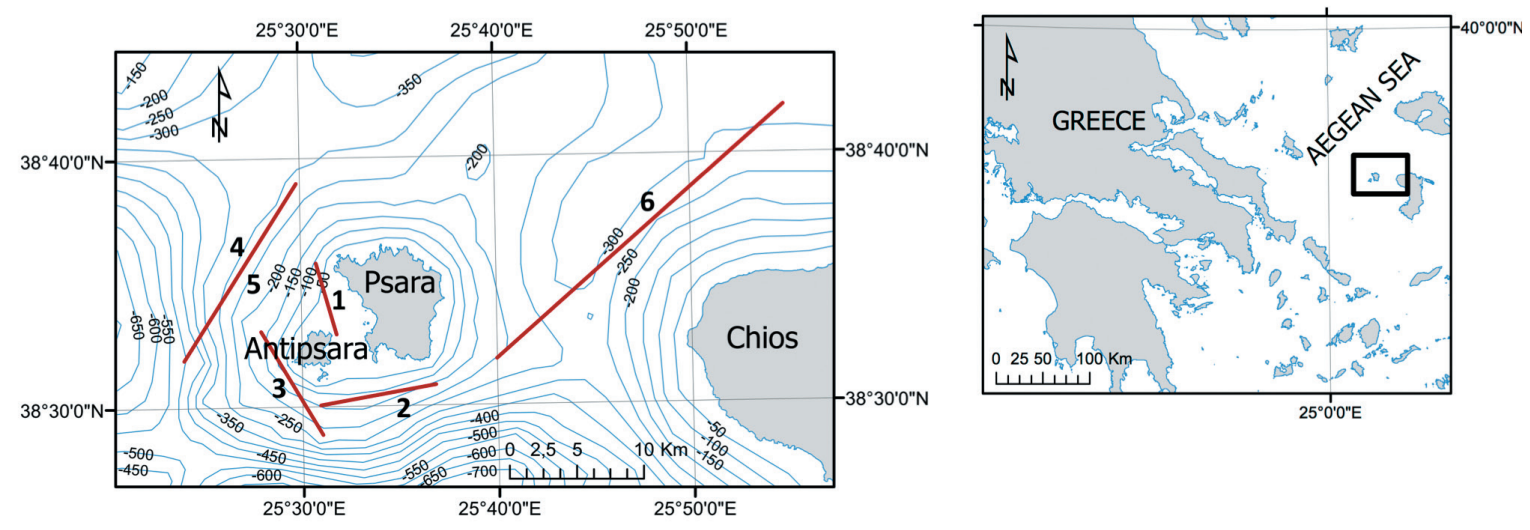

Fig. 1. Map of the study area, indicating with red lines the geographic locations of the hauls 
EVAGELOPOULOS et al.:Length-weight relationships of 9 commercial fish species from the North Aegean Sea 189

Table 1. Length-weight relationships and growth patterns for 9 commercial fish species from Psara Island (N. Aegean Sea, Greece). $p$ values for all species were $<0.001$.

\begin{tabular}{|c|c|c|c|c|c|c|c|c|c|c|c|}
\hline \multirow[t]{2}{*}{ Family } & \multirow[t]{2}{*}{ Species } & \multicolumn{3}{|c|}{$\mathrm{n}$ Length $(\mathrm{cm})$} & \multicolumn{2}{|c|}{ Weight $(\mathrm{g})$} & \multirow{2}{*}{$\frac{\mathrm{a}}{\mathrm{est}}$} & \multicolumn{2}{|c|}{$\mathrm{b}$} & \multicolumn{2}{|c|}{$\mathrm{R}^{2}$ Growth } \\
\hline & & & $\min$ & $\max$ & $\min$ & $\max$ & & est & SE & & \\
\hline Carangidae & $\begin{array}{l}\text { Trachurus picturatus } \\
\text { (Bowdich, 1825) }\end{array}$ & 75 & 25.4 & 42.0 & 120 & 560 & 0.011 & 2.905 & 0.153 & 0.83 & I \\
\hline Merlucciidae & $\begin{array}{l}\text { Merluccius merluccius } \\
\text { (Linnaeus, 1758) }\end{array}$ & 152 & 17.0 & 66.4 & 40 & 1950 & 0.006 & 3.048 & 0.065 & 0.94 & I \\
\hline Mullidae & $\begin{array}{l}\text { Mullus surmuletus } \\
\text { (Linnaeus, 1758) }\end{array}$ & 96 & 13.0 & 27.5 & 23 & 200 & 0.012 & 2.945 & 0.107 & 0.89 & I \\
\hline Sebastidae & $\begin{array}{l}\text { Helicolenus } \\
\text { dactylopterus (Delaroche, } \\
1809 \text { ) }\end{array}$ & 92 & 11.1 & 25.4 & 20 & 254 & 0.017 & 2.933 & 0.078 & 0.94 & I \\
\hline Sparidae & $\begin{array}{l}\text { Boops boops } \\
\text { (Linnaeus, 1758) }\end{array}$ & 48 & 15.5 & 23.3 & 22 & 103 & 0.001 & 3.559 & 0.102 & 0.96 & $\mathrm{~A}+$ \\
\hline Sparidae & $\begin{array}{l}\text { Dentex maroccanus } \\
\text { (Valenciennes, 1830) }\end{array}$ & 67 & 11.0 & 21.1 & 70 & 470 & 0.047 & 3.017 & 0.042 & 0.99 & I \\
\hline Sparidae & $\begin{array}{l}\text { Pagrus pagrus } \\
\text { (Linnaeus, 1758) }\end{array}$ & 23 & 21.4 & 48.2 & 139 & 1580 & 0.018 & 2.927 & 0.053 & 0.99 & I \\
\hline Rajidae & $\begin{array}{l}\text { Raja clavata } \\
\text { Linnaeus, } 1758\end{array}$ & 42 & 32.5 & 68.5 & 189 & 1880 & 0.004 & 3.097 & 0.088 & 0.97 & I \\
\hline Scyliorhinidae & $\begin{array}{l}\text { Scyliorhinus canicula } \\
\text { (Linnaeus, 1758) }\end{array}$ & 160 & 16.0 & 48.0 & 8 & 450 & 0.001 & 3.382 & 0.063 & 0.95 & $\mathrm{~A}+$ \\
\hline
\end{tabular}

$\mathrm{n}=$ sample size. OLS linear regression: $\mathrm{a}$ est $=$ estimate of the intercept, $\mathrm{b}$ est, $\mathrm{SE}, \mathrm{p}=$ estimate of the slope, its standard error and the associated $\mathrm{p}$-value, $\mathrm{R}^{2}=$ coefficient of determination. Growth: $\mathrm{A}+=$ positive allometric, $\mathrm{I}=$ isometric

Overall, the estimated $b$ values for the species studied were close to the mean $b$ values given in FishBase, with one exception; the estimated $\mathrm{b}$ value for $B$. boops was much higher than the mean value given by FishBase $(\mathrm{b}=$ $3.08, \mathrm{SD}=0.1594)$. Similarly high $\mathrm{b}$ values have been reported for $B$. boops from the Aegean Sea by KARAKULAK et al. (2006) for the area of Gökceada Island and KARA \& BAYHAN (2008) for Izmir Bay ( $b=3.258$ and 3.419, respectively), as well as by CAMPILLO (1992) for the Gulf of Lions, Western Mediterranean $(b=3.298)$. Conversely, the $\mathrm{b}$ values reported for B. boops for the Greek seas Evvoikos Gulf (PETRAKIS \& STERGIOU, 1995), the Cyclades archipelago (MOUTOPOULOS \& STERGIOU, 2002), and Korinthiakos Gulf (MOUTOPOULOS et al., 2013), were much lower than the estimate here $(b=3.093,2.877$ and 3.098, respectively), as were the $\mathrm{b}$ values reported in studies for the Western Mediterranean (e.g. VALLE et al., 2003; $\mathrm{b}=2.812$ ) or the Northeastern Atlantic (e.g. TORRES et al., 2012; $\mathrm{b}=2.842$ ). Generally, differentiations in the $b$ parameter of the LWR between studies could be attributed to factors such as the area and season that the fish were caught, the life-history stage of the fish, or the nutritional state of the fish (FROESE, 2006), but they could also be due to sample differences in the length ranges of the fish.

To our knowledge, there are no published data on the fish stocks of the study area. In this contribution, estimates for the LWR parameters for 9 commercial species are provided. The species studied included Dentex maroccanus, Trachurus picturatus and Helicolenus dactylopterus, for which reliable LWR estimates are few in the literature, while none has been published for the Greek seas (FROESE \& PAULY, 2017). There is a total of only five LWR estimates available for D. maroccanus in FishBase: two from the Eastern Atlantic (NGUYEN \& WOJCIECHOWSKI, 1972; MENNES, 1985) and three from the Aegean Sea (KARAKULAK et al., 2006; CEYHAN et al., 2009; GUL et al., 2014). LWR estimates for D. maroccanus from the Aegean Sea were also presented by ISMEN et al. (2007). Moreover, except for the 
studies of ISMEN et al. (2007) and GUL et al. (2014), the sample sizes in the aforementioned datasets are very small, $<10$ individuals. Our estimates for the LWR parameters for $D$. maroccanus are similar to those of GUL et al. (2014) for Saros Bay, which is located at the northernmost part of the Aegean Sea. Concerning T. picturatus, there are only five datasets available in FishBase: four from the Eastern Atlantic (ISIDRO, 1990; BORGES et al., 2003; MENDES et al., 2004; TORRES et al., 2012) and a single dataset from the Western Mediterranean (MERELLA et al., 1997). To our knowledge, there are no LWR estimates for $T$. picturatus from the Eastern Mediterranean published in the literature. Furthermore, although the maximum length recorded for this species in this study is smaller than the known $\mathrm{L}_{\max }=60 \mathrm{~cm} \mathrm{TL}$ (FROESE \& PAULY 2017), it is still higher than in any of the aforementioned datasets. Lastly, LWR estimates for Helicolenus dactylopterus from the Western Mediterranean have been published by CAMPILLO (1992) and MERELLA (1997) and from the Aegean Sea by FILIZ \& BILGE (2004). The present study contributes with a dataset with a wider size range and a higher maximum length.

We consider the main limitations of the present study to be the sampling period not extending over a full year cycle, the sample sizes not being optimal for some of the species studied and the non-differentiation between sexes. Nevertheless, our results provide new information about the LWR of nine fish species of commercial interest from the southernmost part of the North Aegean Sea, while our results for Dentex maroccanus, Trachurus picturatus and Helicolenus dactylopterus are of a broader interest.

\section{ACKNOWLEDGEMENTS}

The authors would like to thank Niki ALEXIOU, Vasilis GEROVASILEIOU, Maria SINI and Thomas VARVERIS for their keen participation in the fieldwork. Thanks are also due to Stuart COCHRANE for the language editing of the manuscript. This study was carried out in the framework of the Research Project "Assessment of the oceanographic and fisheries attributes of the marine area around Psara Island - Preliminary Management Plan for the establishment of a Marine Park" and was funded by the Prefecture of Chios.

\section{REFERENCES}

BORGES, T.C., S. OLIM \& K. ERZINI 2003. Weightlength relationship for fish species discarded in commercial fisheries of the Algarve (southern Portugal). J. Appl. Ichthyol., 19 (6): 394-396.

CAMPILLO, A. 1992. Les pêcheries françaises de Méditeranée: synthèse des connaissances. Retreived from http://archimer.ifremer. fr/doc/1992/rapport-1125.pdf. Accessed $12 / 21 / 2015$

CEYHAN, T., O. AKYOL \& M. ERDEM 2009. Lengthweight relationships of fishes from Gökova Bay, Turkey (Aegean Sea). Turk. J. Zool., 33: 69-72.

FILIZ, H. \& G. BILGE 2004. Length-weight relationships of 24 fish species from the North Aegean Sea, Turkey. J. Appl. Ichthyol., 20: 431-432.
FOX, J. 1997. Applied regression analysis, linear models, and related methods. Thousand Oaks, Sage Publications, 624 pp.

FROESE, R. 2006. Cube law, condition factor and weight-length relationships: history, metaanalysis and recommendations. J. Appl. Ichthyol., 22: 241-253.

FROESE, R. \& D. PAULY 2017. Fish Base. Available from http://www.fishbase.org. Accessed $1 / 6 / 2017$

FROESE, R., A.C. TSIKLIRAS \& K.I. STERGIOU 2011. Editorial note on weight-length relations of fishes. Acta Ichthyol. Piscat., 41 (4): 261263.

GUL, G., A. ISMEN \& M. ARSLAN 2014. Age, growth, and reproduction of Dentex maroccanus (Actinopterygii: Perciformes: Sparidae) in the Saros Bay (north Aegean Sea). Acta Ichthyol. Piscat., 44 (44): 295-300. 
ISIDRO, H.A. 1990. Age and growth of Trachurus picturatus (Bowdich, 1825) (Teleostei: Carangidae) from the Azores. Arquipélago, Sér. Ci. Nat., 8: 45-54.

ISMEN, A., O. OZEN, U. ALTINAGAC, U. OZEKINCHI, \& A. AYAZ 2007. Weight-length relationships of 63 fish species in Saros Bay, Turkey. J. Appl. Ichthyol., 23: 707-708.

JENNINGS, S., KAISER, M., REYNOLDS, J.D., 2001. Marine Fisheries Ecology. Wiley-Blackwell, Malden MA. 417 pp.

KARA, A. \& B. BAYHAN 2008. Length-weight and length-length relationships of the bogue Boops boops (Linneaus, 1758) in Izmir Bay (Aegean Sea of Turkey). Belg. J. of Zool., 138 (2): 154-157.

KARAKULAK, F.S., H. ERK \& B. BILGIN 2006. Length-weight relationships for 47 coastal fish species from the northern Aegean Sea, Turkey. J. Appl. Ichthyol., 22: 274-278.

LE CREN, E.D. 1951. The length-weight relationship and seasonal cycle in gonad weight and condition in the perch (Perca fluviatilis). J. Anim. Ecol., 20 (2): 201-219.

MENDES, B., P. FONSECA \& A. CAMPOS 2004. Weight-length relationships for 46 fish species of the Portugese west coast. J. Appl. Ichthyol., 20: 355-361.

MENNES, F. 1985. Multispecies assessment of fish stocks off the Western Sahara region with emphasis on the family Sparidae. Fishbyte, 3 (3): 5-10.

MEREllA, P., A. QUETGLAS, F. ALEMANY \& A.
CARBONELL 1997. Length-weight relationship of fishes and cephalopods from the Balearic Islands (western Mediterranean). Naga ICLARM Q., 20 (3/4): 66-68.

MOUTOPOULOS, D.K. \& K.I. STERGIOU 2002. Length-weight and length-length relationships of fish species from the Aegean Sea (Greece). J. Appl. Ichthyol., 18: 200-203.

MOUTOPOULOS, D.K., A. RAMFOS, A. MOUKA \& G. KATSELIS 2013. Length-weight relations of 34 fish species caught by small-scale fishery in Korinthiakos Gulf (Central Greece). Acta Ichthyol. Piscat., 43(1): 57-64.

NGUYEN, X.L. \& J. WOJCIECHOWSKI 1972. Comparative biology of fish from genus Dentex (Sparidae) of north-west African coast. Acta Ichthyol. Piscat., 2 (2): 77-79.

PETRAKIS, G. \& K.I. STERGIOU 1995. Weightlength relationships for 33 fish species in Greek waters. Fish. Res., 21: 465-469.

R CORE TEAM 2017. R: A Language and Environment for Statistical Computing. R Foundation for Statistical Computing, Vienna, Austria. Available from https://www.R-project. org. Accessed 6/1/2017.

TORRES, M.A., F. RAMOS \& I. SOBRINO 2012. Length-weight relationships of 76 fish species from the Gulf of Cadiz (SW Spain). Fish. Res., 127-128: 171-175.

VALLE, C., J.T. BAYLE \& A.A. RAMOS 2003. Weightlength relationships for selected fish species of the western Mediterranean Sea. J. Appl. Ichthyol., 19: 261-262. 


\title{
Dužinsko-maseni odnos za 9 komercijalnih vrsta riba iz sjevernog Egejskog mora
}

\author{
Athanasios EVAGELOPOULOS*, Ioannis BATJAKAS i Drosos KOUTSOUBAS
}

*Kontakte-adresa: tevagelo@marine.aegean.gr

\begin{abstract}
SAŽETAK
Prikazani su dužinsko-maseni odnosi za 9 komercijalnih vrsta riba s otoka Psara (sjever Egejskog mora). Istraživane vrste su bukva (Boops boops), marokanski zubatac Dentex maroccanus, bodečnjak veliki (Helicolenus dactylopterus), oslić (Merluccius merluccius), trlja kamenjarka (Mullus surmuletus), pagar (Pagrus pagrus), raža kamenica (Raja clavata), mačka bljedica (Scyliorhinus canicula) i šarun golemi (Trachurus picturatus). Prema saznanjima, nema objavljenih podataka o ribljem fondu ovog istraživanog područja. Procjena parametara dužinsko-masenog odnosa (LWR) iznesena je za zubaca Dentex maroccanus, šaruna golemog (Trachurus picturatus) i bodečnjaka velikog (Helicolenus dactylopterus), za koje u literaturi postoje malobrojni pouzdani podaci o dužinsko-masenom odnosu, dok nema nikakvih objavljenih podataka za mora oko Grčke. Uzorci su prikupljani iz epikontinentalnog pojasa i gornjeg nagiba koristeći neselektivne ribolovne alate (istraživačko plovilo i komercijalna pridnena koćarica) tijekom dva sezonska razdoblje uzorkovanja u studenom 2009. i svibnju 2010. godine. Rast bukve i mačke bljedice alometrijski je pozitivan, dok je izometrični uzorak rasta uočen kod drugih istraživanih vrsta. Smatra se da će dužinskomaseni odnos koji je ovdje uočen biti ubuduće korišten prilikom upravljanja ribarstvom ili prilikom konverzacijskih istraživanja u istraživanom području, primjerice pretvorbom dužine u širinu, određivanja stanja ribe i procjene prostornih i vremenskih varijabilnosti u rastu riba.
\end{abstract}

Ključne riječi: povijest života, rast životinja, upravljanje u ribarstvu, pridneno ribarstvo, pridneno koćarenje, marokanski zubatac 